\begin{tabular}{|l|l|l||}
\hline \multicolumn{2}{|c|}{ PublisherInfo } \\
\hline \hline PublisherName & $:$ & BioMed Central \\
\hline \hline PublisherLocation & $:$ & London \\
\hline \hline PublisherImprintName & $:$ & BioMed Central \\
\hline \hline
\end{tabular}

\title{
Histone modification in heterochromatin
}

\begin{tabular}{|l|l|l||}
\hline \multicolumn{2}{|c|}{ ArticleInfo } \\
\hline \hline ArticleID & $:$ & 4409 \\
\hline \hline ArticleDOI & $:$ & $10.1186 /$ gb-spotlight-20020225-01 \\
\hline \hline ArticleCitationID & $:$ & spotlight-20020225-01 \\
\hline \hline ArticleSequenceNumber & $:$ & 75 \\
\hline \hline ArticleCategory & $:$ & Research news \\
\hline ArticleFirstPage & $:$ & 1 \\
\hline \hline ArticleLastPage & $:$ & 2 \\
\hline \hline & & RegistrationDate : 2002-2-25 \\
\hline ArticleHistory & $:$ & OnlineDate \\
\hline \hline ArticleCopyright & $:$ & BioMed Central Ltd2002-25 \\
\hline \hline ArticleGrants & $:$ & \\
\hline \hline ArticleContext & $:$ & 130593311 \\
\hline \hline
\end{tabular}




\section{Jonathan B Weitzman}

Email: jonathanweitzman@hotmail.com

Modification of histone tails, by acetylation, methylation or phosphorylation, affects the local chromatin structure and the transcriptional regulation of adjacent genes. Pericentric heterochromatin contains hypoacetylated and methylated histone $\mathrm{H} 3$ that result in transcriptional silencing. In an Advanced Online Publication from Nature Genetics, Maison et al. describe the use of antibodies recognizing specific histone modifications to explore the nature of pericentric heterochromatin organisation (19 February 2002, DOI:10.1038/ng843). Antibodies raised against methylated branched H3 peptides recognized nuclear dots that localized at pericentric heterochromatin domains in mouse cells. Treatment with histone deacetylase inhibitors affected the pattern of antibody staining and pericentric heterochromatin, suggesting that deacetylation plays a role in maintaining higher-order chromatin structure and spatial organization. Maison et al. also report that an RNA component is required for this structural organization.

\section{References}

1. Translating the histone code.

2. Nature Genetics, [http://www.nature.com/ng] 